\title{
Seasonal residence and counterurbanization: the role of second homes in population redistribution in Finland
}

\author{
Czesław Adamiak $\cdot$ Kati Pitkänen • Olli Lehtonen
}

Published online: 9 June 2016

(C) The Author(s) 2016. This article is published with open access at Springerlink.com

\begin{abstract}
Since the late twentieth century, many developed countries have experienced population deconcentration, labelled as counterurbanization. There has been an academic discussion on the meaning, validity and universality of this concept, drivers of counterurbanization and its impacts on rural areas. To date, research on counterurbanization mostly apply static and discrete definitions of residence, migration and population, which is an increasingly simplistic view in the contemporary reality of a growing multitude of forms of mobility, often related to dual residence. Particularly large-scale quantitative studies on counterurbanization are confined by existing statistical practices. This paper attempts to overcome this obstacle and describe the transformation of the settlement system in Finland acknowledging the role of second home mobility. To achieve this goal, it introduces two alternative measures of population,
\end{abstract}

C. Adamiak ( $\square)$

Faculty of Earth Sciences, Nicolaus Copernicus

University, Toruń, Poland

e-mail: czeslaw.adamiak@umk.pl

\section{K. Pitkänen}

Environmental Policy Centre, Finnish Environment Institute (SYKE), Joensuu, Finland

e-mail: kati.pitkanen@ymparisto.fi

\section{O. Lehtonen}

Rural Policy and Rural Research, Natural Resources Institute Finland, Helsinki, Finland

e-mail: olli.lehtonen@luke.fi seasonal and average population, and analyses their spatial dynamics between the years 1990 and 2010 based on georeferenced grid statistical data. The study finds that although registered population has been concentrating during the period in analysis, seasonal population has been increasingly dispersed due to the growing number of second homes. It shows that the counterurbanization process, though not noticed by conventional statistics, does occur in Finland, manifested by seasonal rather than permanent moves. The article concludes that various forms of mobility should be taken into account when analysing the urban-rural population dynamics and transformations of settlement systems as well as in rural development planning.

Keywords Second homes - Seasonal population · Counterurbanization · Population deconcentration . Finland

\section{Introduction}

Population concentration and deconcentration are among the central themes in population geography. Since the beginning of the industrialization era, urbanization has led to an increasing population concentration in urban areas, often paralleled by the depopulation of rural regions. Since the 1970s, an opposite counterurbanization trend has been observed in many developed countries, interpreted as a result of 
the traditionally dominant economy-driven rural-tourban movements being outnumbered by urban-torural migrations oriented on higher quality of life (Berry 1976; Champion 1989). The increase in research on counterurbanization has brought conceptual confusion around the topic manifested in an essential discrepancy in the understanding of counterurbanization either as a form of individuals' migratory movement from urban to rural areas, or as a process of settlement system transformation into a more dispersed form (Mitchell 2004).

Studies on counterurbanization usually adopt static definitions of residence (as a fixed characteristic of a person, which can be shifted in the event of migration) and population (as a characteristic of a place, which can change over time, but ideally is measureable at any moment). Such assumptions are being increasingly challenged by contemporary social science on human mobility (Hall 2005; Urry 2007). It has been suggested that the notions of home, place of residence, migration, and population do not suffice to understand increasingly diverse forms of mobilities, often related to tourism and multiple residence (McIntyre et al. 2006). Attempts to acknowledge temporary mobility in population measures have been mainly made within tourism studies (Terrier 2006; Rigall-i-Torrent 2010). Müller and Hall (2003) estimated seasonal population redistribution related to second home use in Sweden. However, the pursuits to describe seasonal population lack connection to the scholarly literature on urban-rural population dynamics. Such linkage could enrich the discussion on counterurbanization which, as Halfacree (2012) suggests, should not be confined to the study of permanent migrations only, but should instead consider the whole spectrum of temporary mobilities from commuting through leisure visits and second home use.

In the Nordic countries, statistics on registered population show that the concentration in urban areas continues to dominate over a contrary population flow (Heikkilä 2003; Lehtonen and Tykkyläinen 2009). In Finland, in particular, the extensive urbanisation process is of relatively recent origin, as it started only in the 1960s, and since then it has caused negative impacts on the economic development prospects and living environments of rural areas (Lehtonen 2015; Lehtonen and Tykkyläinen 2010). It has been hoped that the decline in rural population and income base could be offset by migration from cities, especially of retired households looking to return to their rural roots and lifestyle migrants (Jauhiainen 2009). However, no large-scale urban to rural migration has taken place, one of the explanations being that the quality of life motives, elsewhere linked to urban-to-rural migration, in the Nordic region are rather satisfied by the extensive access to rural second homes (Müller 2011; Niedomysl and Amcoff 2011; Hiltunen et al. 2013). It has been estimated that half of the population of the Nordic countries has an access to a second home and these are increasingly used year-round. Hence, instead of permanent moves people increasingly opt for sharing their lives between an urban permanent residence and a rural second home (Adamiak et al. 2015). Second homes have largely been ignored in rural policies and local planning based on registered permanent population figures, although a growing number of studies have pointed at their importance as a way to balance the negative effects of depopulation of rural communities and secure their future by helping to preserve services and employment (Müller 2002; Marjavaara 2008; Hiltunen et al. 2013).

This paper explores the spatial patterns of population development in Finland between 1990 and 2010. We present a way to acknowledge the role of temporary mobility in the process of settlement system transformation, in response to the appeals for including the diversity of human mobilities into the population geography. Moreover, we aim to reveal the spatial patterns of population deconcentration hidden under the phenomenon of second homes. To achieve these goals, we introduce two alternative measures of population: seasonal and average population, and analyse their dynamics between 1990 and 2010 using grid statistical data, complemented with more in-depth survey data on the access and use of second homes in Finland. We use Finland as case study for three reasons: the strong and ongoing urbanization process that the country is going through and related weakening development prospects of the rural areas; the large scale of second home mobility; and the availability of unique GIS and survey data that enabled us to perform a detailed quantitative study.

\section{Background}

Counterurbanization as migration and a process of settlement system transformation

Urbanization, defined as the process of increasing concentration of population in cities (Tisdale 1942) 
has transformed Europe from predominantly rural into urban during the recent two centuries. In many countries, massive migrations from rural areas to cities lead to population decline in rural regions undermining their economic performance and causing adverse social consequences (van der Berg et al. 1982; Dahms 1995; Stockdale 2002; Rye 2006). Most of the developed countries reached the ceiling of rapid urbanization in the course of the twentieth century, and the unidirectional transformation gave way to more complex patterns of urban-rural population dynamics (Champion 2001). In the 1970s, a reversal of the urban concentration process was noticed in the USA and many western European countries, which many scholars interpreted as a sign of a turnaround of the dominant trend into population deconcentration. Counterurbanization was interpreted to be driven by the increasing importance of quality of life and postFordist economic transformation (Berry 1976; Champion 1989; Vartiainen 1989a).

The predictions of deconcentration becoming a widespread and dominant population tendency (Vining and Strauss 1977) have been largely criticized by later studies. The generalizability of this development has not found support from statistical sources (Champion 2001). Long-wave economic trends and nonlinear evolutionary models were used to explain temporary, rather than permanent, character of population deconcentration (van der Berg et al. 1982; Berry 1988; Geyer and Kontuly 1993). Moreover, it has been debated to what extent statistical observations prove actual rural growth rather than a territorial expansion of cities: urban spillover or suburbanization (Gordon 1979; Kontuly and Vogelsang 1988; Amcoff 2006). Also, the population dynamics between urban and rural areas are nowadays attributed to a wide spectrum of general and place-specific factors shaping urbanrural movements, but also international migrations and natural increase (Champion 1989; Dahms 1995; Hoggart 1997; Mitchell 2004; Johnson et al. 2005).

The term counterurbanization is nowadays used not only to name a process of settlement system transformation, but also a migratory movement from urban to rural areas (Mitchell 2004). Such migration may, but does not need to change the urban-rural population balance, because it is usually accompanied by an opposite rural-to-urban migration, as well as other migratory and natural movements. Yet, it alters the structure of rural population and brings various economic and social consequences to rural communities (Hoggart 1997; Boyle and Halfacree 1998; Milbourne 2007; Phillips 2010). Urban-to-rural movement has traditionally been attributed to relatively wealthy families of middle-aged adults seeking a more natural and relaxed dwelling environment (Boyle and Halfacree 1998; Gosnell and Abrams 2011; Šimon 2012). Locally, such migration is most commonly directed to areas of special natural appeal as sea coasts and mountains (Magnusson and Turner 2003; McGranahan 2008), and thus labelled as amenity migration (Gosnell and Abrams 2011; Moss 2006). Still, contemporary urban-to-rural migration is not limited to the middle-class quality of life seekers. Considerable groups are also driven by economic factors: employment possibilities, lower costs of life or life events such as retirement (including return migrations), unemployment, indebtedness, marriage, divorce (Mitchell 2004; Pehkonen 2005; Stockdale 2006; Halfacree 2008; Jauhiainen 2009; Šimon 2012). Also international immigration, which traditionally focused on urban areas, is increasingly targeted to rural areas (Milbourne 2007; Hedberg and Haandrikman 2014).

There is an inconsistency in defining counterurbanization, with basic discrepancy between the individual mobility approach and the settlement system approach. To solve this problem Mitchell (2004) proposed to apply three terms instead of a single one and she built a conceptual model explaining causal relations between them. She defined counterurbanization as the migratory movement from urban to rural areas. It is one of the factors, along with natural increase and other domestic and international migrations, that may cause counterurbanizing process, understood as a process of deconcentration of settlement system, which eventually leads to the creation of a counterurban settlement pattern. Although the usability of these terms may be debated, such a distinction is helpful for discussing how second home mobility can be suited within these concepts.

Counterurbanization and second homes

Many of the motives that explain migrations from urban to rural areas, such as escape from urban life, the appeal of natural environment, and willingness to own or build a home, are also identified as important motives for the ownership of second homes (Jaakson 
1986; Kaltenborn 1998; Hall and Müller 2004). The development of second homes also raises similar issues of social and economic interactions as permanent migration and second home use sometimes leads to a permanent move into rural area (Williams and Hall 2000; Marjavaara and Lundholm 2014). In fact, some previous studies have treated second home ownership and seasonal residence as a manifestation of amenity migration (McCarthy 2008) or counterurbanization (Buller and Hoggart 1994). Referring to the conceptualization of counterurbanization Halfacree (2012) has pressed for acknowledging the wide spectrum of mobility from transit visits through seasonal second home use to permanent residence, as all have common motives and impacts but differ in their temporal scope. It thus seems that research in counterurbanization, understood as mobility (Mitchell 2004), has more or less consciously accepted second homes as a part of this phenomenon.

Previous studies on counterurbanization as a settlement system transformation (counterurbanizing) process (Mitchell 2004), in turn, are mostly based on large-scale register-based quantitative analyses. Hence, they rely on statistical practices which treat places of residence as static and discrete points, and population as a measurable characteristic of a territorial unit. Attempts to measure population distribution and dynamics acknowledging temporary and seasonal mobility often come from tourism studies (Bell and Ward 2000; Terrier 2006). Some research employ indirect methods of assessing seasonal population changes such as travel surveys (Charles-Edwards and Bell 2015), data on the usage of water, electricity and waste production (Rigall-i-Torrent 2010) and mobile phone tracking (Silm and Ahas 2010), but the possibilities of their application are usually limited in space and time. Müller and Hall (2003) estimated the adjusted distribution of population in Swedish municipalities taking into account the distribution of second homes, places of permanent residence of their owners, average numbers of visitors and average yearly time spent in second homes. The resulting population estimations were significantly different than the official numbers: urban municipalities lost, while some peripheral rural municipalities gained over $10 \%$ more residents. Following Mitchell's (2004) conceptualization we can say that the authors revealed a more counterurban settlement pattern hidden under the apparently more concentrated one suggested by the official population statistics. Yet the authors performed a static analysis and did not investigate the counterurbanizing process, thus how the settlement system has changed over time due to the second home use.

The measurement of seasonal variability of population has significant practical implications for rural policy. In most countries, people can register only one official place of residence where their citizenship rights are tied to. These official registered population figures work as the basis for tax distribution, often putting communities with high numbers of secondary dwellings in an unfavourable situation (Müller and Hall 2003). The need to take into account seasonal population in rural planning policies was noticed already in the 1970s (Ragatz 1970; Coppock 1977) and it is further augmented by hopes and fears associated with the development of second homes. These are similar to those related to permanent migration into rural areas. On the one hand, second home users to some degree replace population moving out, help to maintain social fabric and demand for local services. On the other hand, the development of second homes may lead to conflicts with local population, and competition for resources sometimes resulting in the displacement of local residents. The impacts of second home development vary depending on national and local context (Hall and Müller 2004; Gallent et al. 2005; Farstad 2013; Hall 2014).

Urban-rural population dynamics and second homes in Finland

In recent decades, Finnish population has increasingly concentrated in cities, which has been accompanied by the depopulation of rural areas (Alestalo 1983; Kupiszewski et al. 2000; Pekkala 2003). A symptom of population deconcentration has been noticed in the 1970s when the populations of some peripheral regions in central and northern Finland started to increase, but it happened only thanks to the growth of main cities of these regions, while the rural areas were continuously loosing population (Vartiainen 1989b; Heikkilä 2003; Hätälä and Rusanen 2010). Urban-torural migration in Finland is varied in terms of time, space, motives and social composition. It includes return migration of retired people, voluntary and economic migration of families to suburban areas and former residences to peripheral areas. It does not 
however suffice to supplement the dominating ruralto-urban flow (Heikkilä 2003; Pekkala 2003; Pehkonen 2005), resulting in continuous depopulation and economic stagnation of sparsely populated peripheral areas (Lehtonen and Tykkyläinen 2010; Lehtonen 2015).

To describe the dynamics of registered population in Finland since the 1980s, we use the YKR urbanrural typology, which divides Finnish territory into seven categories based on a complex classification procedure using data on population, labour, commuting, building and land use to measure density, accessibility, versatility and orientation of the areas (Helminen et al. 2014; see Data and Methods for the description of the YKR georeferenced statistical database). From 1980 to 2012 urban and exurban areas have been characterized by a population increase (Fig. 1). The exurban fringe areas spread around and between urban centres and are linked to them by infrastructure and functional relations. In parallel to the population growth in urban and exurban areas, the four categories of rural areas in YKR typology have been mostly characterized by a loss of population. Only rural areas close to urban areas have witnessed a steady population growth during the past decades. Local administrative and service centres in rural areas outside of the reach of urban influence have had relatively stable population numbers. The remaining two rural categories: core rural areas and sparsely populated rural areas, which together cover $84.2 \%$ of the Finnish land area, have experienced a significant loss of population.

Second homes constitute an important part of housing and land use in Finland. They are mostly located in rural areas, and, in contrast to permanent residencies, their number in these areas has been growing during the past decades. According to Statistics Finland, since 1970 the number of second homes has almost tripled from 176 to 500 thousand in 2014, and every fifth of the 317 Finnish municipalities has more second homes than permanent dwellings (OSF 2015). The importance of second homes is further emphasized by the fact that second homes are not only used by their owners, but also by extended family and friends. According to the Longitudinal National Outdoor Recreation Survey (LVVI 2010), about 40 per cent of Finns have a regular access to a second home, thus it may be estimated that each second home in Finland is regularly used by 4.2 people. If also random visits are counted, altogether over 3 million Finns may visit a second home annually (Nieminen 2009). The access rate is slightly higher among urban population and urban residents spend more time in second homes (Table 1). On average, those with an access to a second home spend there 43 days a year. According to the LVVI study, both the share of

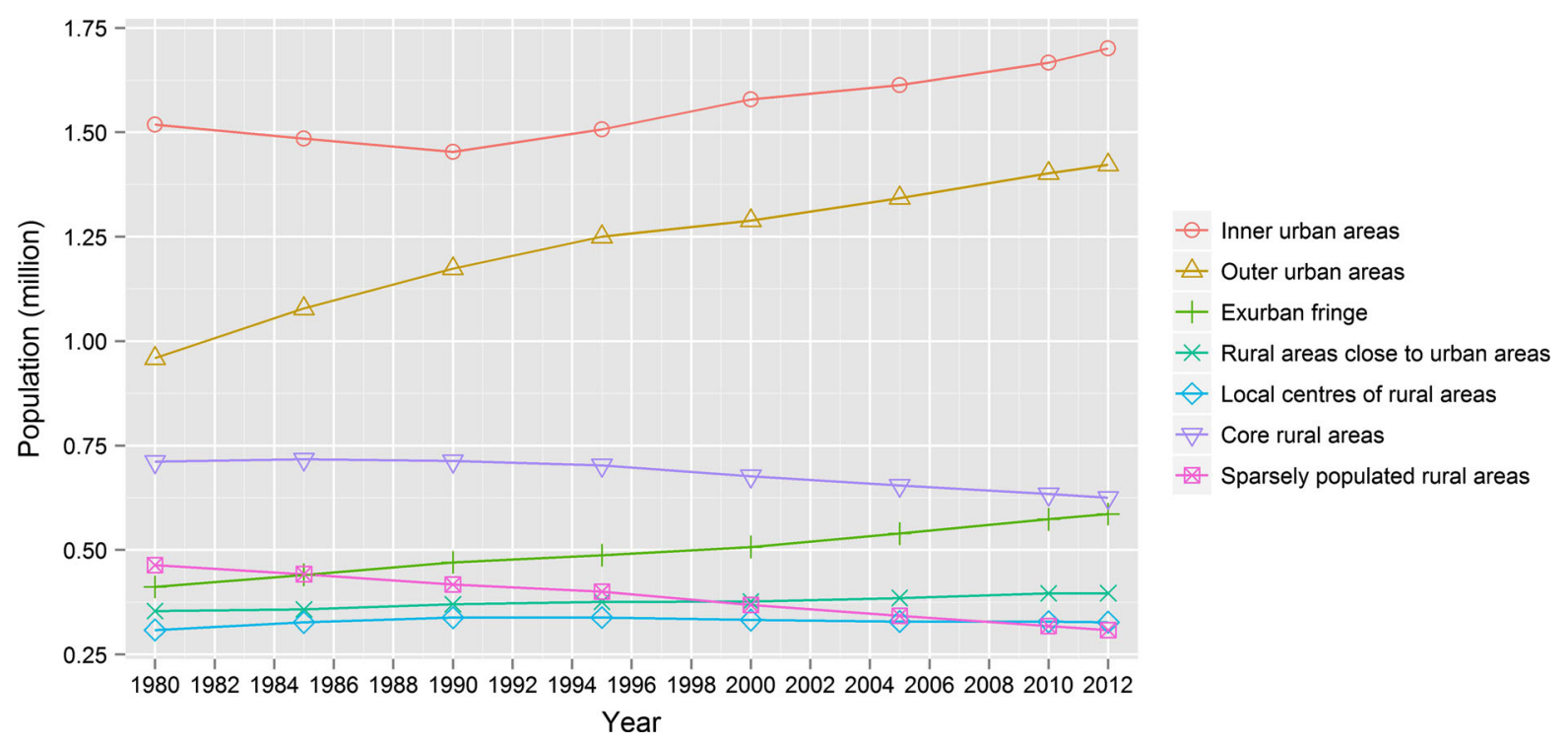

Fig. 1 Change of registered population in Finland between 1980 and 2012 by category of YKR urban-rural typology 
Table 1 Rate of access and average number of days spent at second home by size of municipality of residence. Source: LVVI (2010)

\begin{tabular}{lll}
\hline $\begin{array}{l}\text { Size of municipality } \\
\text { (inhabitants) }\end{array}$ & $\begin{array}{l}\text { Rate of access to second } \\
\text { homes (\% of population) }\end{array}$ & $\begin{array}{l}\text { Average number of days a year } \\
\text { spent at second home }\end{array}$ \\
\hline$<4000$ & 37.1 & 37.2 \\
$4000-9999$ & 39.8 & 37.7 \\
$10,000-24,999$ & 38.8 & 41.4 \\
$25,000-99,999$ & 41.7 & 44.7 \\
$\geq 100,000$ & 41.9 & 45.9 \\
National average & 40.8 & 43.3 \\
\hline
\end{tabular}

population with regular access to second homes and average time spent there have been growing during the past decade.

\section{Data and methods}

Population statistics on sub-national level are usually gathered for territories of administrative units (e.g. municipalities). An alternative approach is to divide the territory into a regular grid of small rectangles of the same size. Population figures and other data are assigned to certain rectangles (grid cells) based on the exact georeferenced locations of places of residence, properties or companies. Statistical grid databases are increasingly used in population studies in the Nordic countries (Amcoff 2006; Kotavaara et al. 2011). Performing spatial population analysis independently from administrative borders helps to avoid several methodological pitfalls, such as the effect of "urban spillover" (Amcoff 2006) or large administrative units covering disparate areas: in Finland, especially in the northern part of the country, municipalities cover large areas which may be predominantly desert but contain municipal towns where local population is concentrated (Muilu and Rusanen 2003; Kauppila and Rusanen 2009).

In our analysis, we use the YKR database (Monitoring System of Spatial Structure and Urban Form), one of the most advanced georeferenced statistical databases in the world enabling to perform nationwide analyses using GIS methods. The YKR database is created and maintained by the Finnish Environment Institute, and it comprises data about population, housing, workplaces and travels to work from the years 1980 to 2010 for each of about 6.3 million
$250 \mathrm{~m} \times 250 \mathrm{~m}$ square-shaped grid cells into which the territory of Finland is divided. We generalized the original data into lower spatial resolution of $5 \mathrm{~km} \times 5 \mathrm{~km}$ cell size, as such resolution is sufficient for the purpose of the study and generalization facilitated computing and graphical presentation of the results.

From the YKR database, we derived the information on the numbers of registered population and properties described as second homes in each grid cell. The term second home refers to buildings used as a leisure-time residencies on the last day of the year (OSF 2015). Due to slight differences in statistical methodologies, the YKR data differs from the data by Statistics Finland. The total number of second homes in the YKR database in 2010 was 517,622. This number contained 489,232 (94.5\%) individually used second homes and 28,390 (5.5\%) commercial second homes rented out to tourists. The commercial second homes could not be excluded from the analysis, because due to privacy protection the database did not provide the detailed proportions between the two categories in part of grid cells. On the other hand, the database does not include all properties used as second homes, as farms converted into second homes, flats used as second homes, allotment garden cottages and rental second homes might be registered for other purposes, usually as residential buildings (OSF 2015). Also, the transformations of the use of properties between primary and secondary residences are often not registered. In our analysis we compare the distribution of population in 1990 and 2010. The choice of that time span enables us to observe the dynamics in the population distribution during the period of economic growth that is said to have contributed to the accelerated concentration of 
population in major urban areas (Lehtonen and Tykkyläinen 2009).

In order to take into account the role of second home use in the population distribution, we analyse not only the changes in the registered population numbers $(R P)$, but we also elaborate two additional measures of population. The seasonal population $(S P)$ measures the number of people expected to be present in given area during the highest tourist season. The average population $(A P)$, in turn, measures the average number of people present at the area throughout a year. To calculate these measures, we use two parameters: the rate of access to second homes and the average length of stays in second homes, estimated for residents of different areas in Finland (Table 1), and based on the results of the Longitudinal National Outdoor Recreation Survey (LVVI 2010) conducted in the years 2009-2010 and targeted to a random sample of almost 9 thousand Finns. To assign these parameters, we differentiated grid cells according to the size of municipalities they belonged to.

Before calculating seasonal and average population, we assigned numbers of second home users (SHU) to each grid cell. For the year 2010 it was calculated as

SHU2010 $i=\operatorname{sh} 2010_{i} *$ users

and for the year 1990 as

SHU1990 $i=s h 1990_{i} *$ users

In these equations $S H U 2010_{i}$ and $S H U 1990_{i}$ variables represent numbers of the users of second homes located in a given grid cell $i$ in the years 2010 and 1990 respectively. The $s h 2010_{i}$ and $s h 1990_{i}$ variables stand for the numbers of second homes in cell $i$ in 2010 and 1990. For 2010 we used the real number of second homes according to YKR data, and for 1990 we used the number of second homes existing in 2010, which were built until 1990 (hence minor inaccuracies may result from possible demolition, abandonment or change of use of second homes between these dates). The constant users denotes the average number of people using one second home, which is 4.2 , based on the LVVI study results. It is assumed to be constant over time due to lack of comparable data from 1990.

Seasonal population $(S P)$ counts the population assuming that everyone who has access to a second home is present at his/her second home, and not in the place of his/her permanent residence. It is not an actual number of population present at the area in any moment of time, because not everyone visits second home at the same time, but considering the high uniformity of the seasonal patterns of second home use in Finland (summer use of second homes predominates in all regions of Finland, including the North where many second homes are located in ski resorts, see Adamiak et al. 2015), it is a fair approximation of population distribution at the peak of the summer season (in July). Seasonal population is calculated by adding the number of second home users to registered population, and subtracting the number of population in the cell expected to leave their permanent residence to visit a second home. For the year 2010:

$$
\begin{aligned}
S P 2010_{i}= & R P 2010_{i}+S H U 2010_{i} \\
& -R P 2010_{i} * \text { access } 2010_{i}
\end{aligned}
$$

and for the year 1990:

$$
\begin{aligned}
S P 1990_{i}= & R P 1990_{i}+S H U 1990_{i} \\
& -R P 1990_{i} * \text { access } 1990_{i}
\end{aligned}
$$

In these equations $S P 2010_{i}$ and $S P 1990_{i}$ variables represent seasonal population of a given grid cell $i$ in the years 2010 and 1990 respectively. $R P 2010_{i}$ and $R P 1990_{i}$ describe registered population in a similar way. The variables access $2010_{i}$ and access $1990_{i}$ denote the shares of grid cell population that had access to a second home in 2010 and 1990. For 2010, these figures varied across municipalities of different sizes based on the LVVI study (see Table 1). For 1990, they were estimated based on the number of second homes in 1990, with the assumption that the average number of users of one second home, as well as the relative differences in access to second homes between municipalities of different sizes did not change until 2010.

The average population $(A P)$ describes the population after taking into account the annual use patterns of primary and second homes. For 2010 it was calculated as

$$
\begin{aligned}
& A P 2010_{i}=R P 2010_{i}+S H U 2010_{i} * \frac{\text { days }}{365} \\
& -R P 2010_{i} * \operatorname{access}_{2010_{i}} * \frac{\text { days }_{i}}{365}
\end{aligned}
$$

and for the year 1990 as 


$$
\begin{aligned}
A P 1990_{i}= & R P 1990_{i}+S H U 1990_{i} * \frac{\text { days }}{365} \\
& -R P 1990_{i} * \text { access } 1990_{i} * \frac{\text { days }_{i}}{365}
\end{aligned}
$$

The constant days describes the national average of the number of days spent in second homes by their users annually (43), and for calculating the seasonal outflow of population this parameter was assigned to a given grid cell $\left(\right.$ days $\left._{i}\right)$ according to the differences between municipalities of different size (Table 1). We used the same values of days for both years: 1990 and 2010 due to the lack of precise data on the average time patterns of second homes use in 1990. However, the mean number of days spent in second homes increased from 31 to 43 only between the years 2000 and 2010 (LVVI 2000, 2010), so our estimation of the change in average population between 1990 and 2010 may be too low.

Change in the registered population between 1990 and 2010 in statistical grid cell $i\left(\Delta R P_{i}\right)$ was calculated as

$$
\Delta R P_{i}=R P 2010_{i}-R P 1990_{i}
$$

and changes in seasonal and average population were calculated accordingly.

We computed the change of each measurement of population for each category of YKR urban-rural typology. Generalized grid cells were classified into YKR urban-rural classification based on the maximum area of a single classification category inside the cell. The exception was made for the local centres of rural areas: a grid cell was classified as such if over $10 \%$ of its area fell into this class.

To present the changes in the overall level of concentration of each measurement of population, we used the Hoover concentration index often applied in population studies before (Hoover 1941; Rogerson and Plane 2012). Hoover index $(H)$ is calculated as half of the sum of differences between shares of population and areas of each territorial unit ( $p_{i}$ and $a_{i}$ respectively) in total population and area of the country $(P$ and $A)$ :

$H=\frac{1}{2} \sum_{i=1}^{n}\left|\frac{p_{i}}{P}-\frac{a_{i}}{A}\right|$

Hoover index value equals 0 when the whole population is distributed uniformly in all territorial units and approaches $1(100 \%)$ when the whole population is concentrated in a small area. The index values can be interpreted as a share of population that needs to be relocated in order to obtain its uniform distribution.

\section{Results}

The spatial patterns of three measures of population described above differ significantly between each other. Registered population (Fig. 2, left map) is concentrated in large urban areas, mostly located in southern Finland (Helsinki, Tampere, Turku) and regional cities in central and northern parts of the country (e.g. Jyväskylä, Kuopio, Oulu), while the rest of Finland is less or sparsely populated. The distribution of second homes and related additional population that can visit the area in summer season is different (Fig. 2, right map): it is concentrated on the coast and archipelagos on the Baltic Sea, in the Lakeland region covering the southern and south-eastern interior of the country, and in some tourism centres in northern Finland (e.g. Kuusamo, Levi and Vuokatti). It can be noticed that outside of urban centres, in a significant part of the country second home users may outnumber permanent residents during high season.

The spatial pattern of seasonal population is affected both by the distribution of permanent population, and second homes (Fig. 3, left map). Seasonal population is concentrated in urban areas, on the Baltic coast, and in the Lakeland region. The difference between permanent and of seasonal population is particularly evident in the case of the Lakeland region which is a popular second home area, easily accessible from the Helsinki region. Taking seasonal population into account also decreases the extent of unpopulated area in Finland from almost $1 / 3$ of its territory, suggested by the registered population figures, to less than $1 / 4$ (Table 2). The spatial pattern of the average population (Fig. 3, right map) is similar to the pattern of registered population. Differences may be noticed in areas with large concentrations of second homes, such as the coastline, resorts in northern Finland, and some parts of the Lakeland, where population count is significantly higher if we consider seasonal influx.

Between 1990 and 2010, the registered population of Finland grew by $7.7 \%$ from 4935 to 5317 thousand. The growth was spatially concentrated: only $16.1 \%$ of the Finnish territory experienced an increase in registered population, while population decreased on 


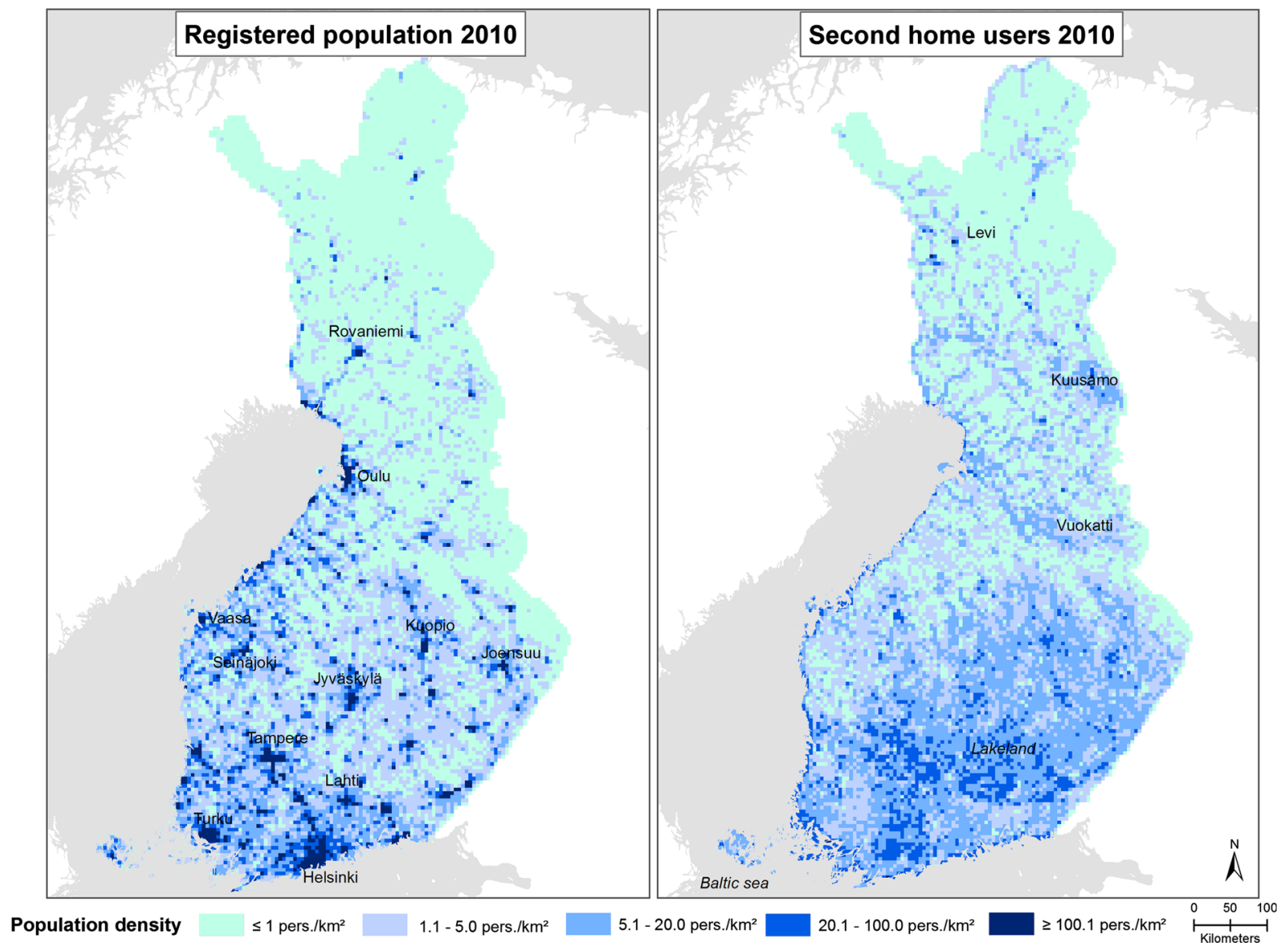

Fig. 2 Distribution of registered population and second home users in Finland in 2010

almost half of the area of the country (Table 2). In contrast, seasonal population increased in the majority of the Finnish territory. The area where the average yearly population grew was geographically over twice as big as the area where the registered population grew, and nearly equalled the area where average population decreased. The difference in the increase in registered and seasonal population is a result of the growth of the number of second homes by $36.2 \%$ in the period in question: from 380 to 518 thousand (according to the YKR data). The number of people that seasonally change their place of residence can be thus estimated to have risen from 1.59 to 2.17 million between 1990 and 2010.

The geographic patterns of changes in the three measures of population between 1990 and 2010 are presented in Fig. 4. In the case of the registered population, the growth was mostly limited to urban and suburban areas of Helsinki, Tampere, Turku,
Oulu, Jyväskylä, and other regional centres. The rest of the country experienced depopulation. Seasonal population, in turn, increased also in the rural areas of the Lakeland, coasts, and in large areas in the North of the country. Seasonal population decreased only in the agricultural western Finland and in areas close to the eastern border. The spatial pattern of the changes of average population is similar to the changes of the registered population, but the depopulating areas are smaller since the depopulation in the amenity-rich areas is compensated by the increasing seasonal population. The results indicate that these areas have not been as depopulated as the statistics of registered population suggest.

Superimposing the geographic patterns of the dynamics of different population measures on the YKR urban-rural classification confirms that the population development between 1990 and 2010 has been related to the settlement hierarchy (Table 3). 


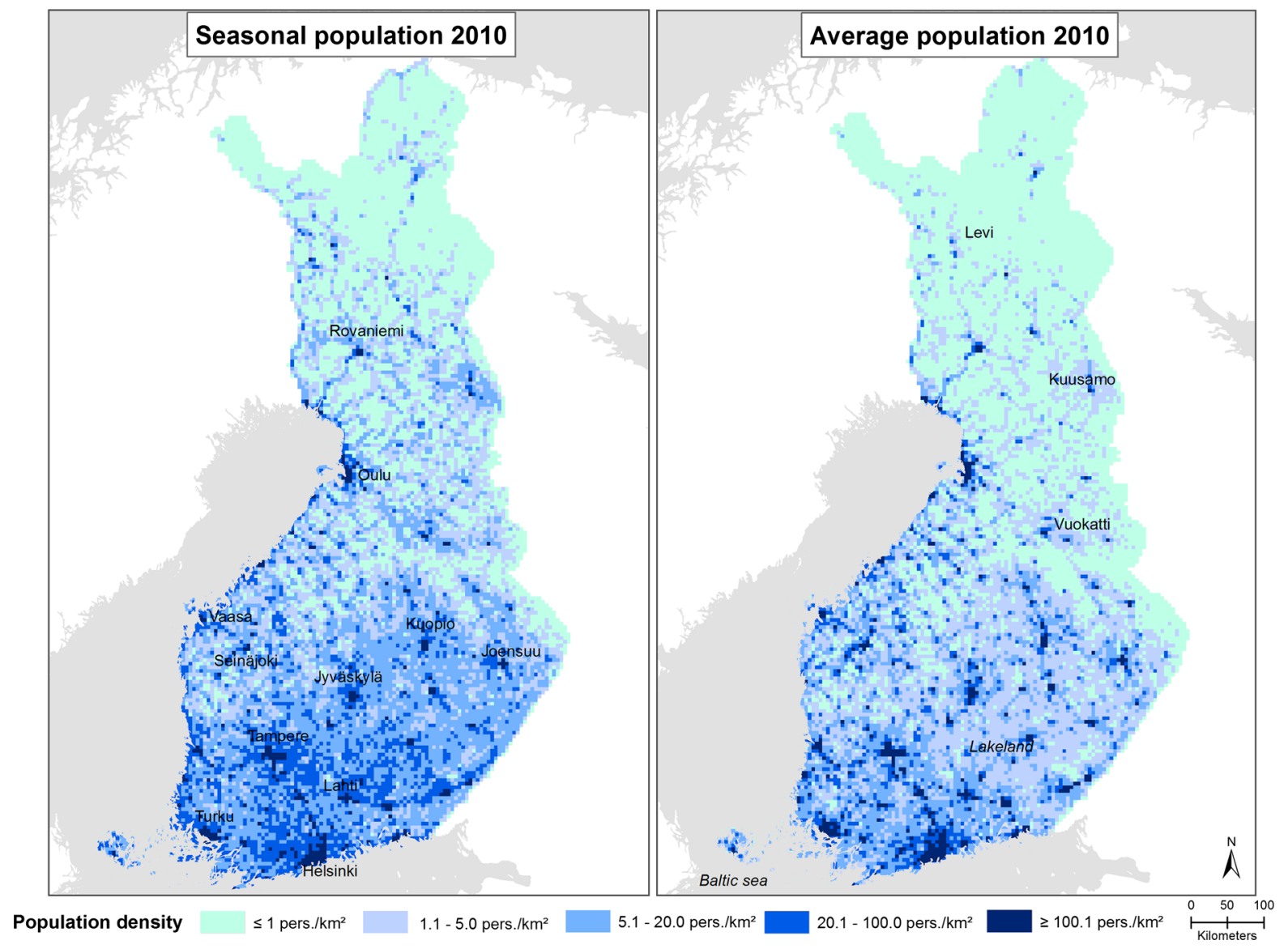

Fig. 3 Distribution of seasonal and average population in Finland in 2010

Table 2 Change of registered, seasonal and average population in Finland between 1990 and 2010

\begin{tabular}{lllll}
\hline & \multicolumn{4}{l}{ Share (\%) of Finnish territory where population } \\
\cline { 2 - 5 } & $\begin{array}{l}\text { Increased between } \\
1990 \text { and 2010 }\end{array}$ & $\begin{array}{l}\text { Did not change between } \\
1990 \text { and 2010 }\end{array}$ & $\begin{array}{l}\text { Decreased between } \\
1990 \text { and 2010 }\end{array}$ & $\begin{array}{l}\text { Area unpopulated } \\
\text { in 1990 and 2010 }\end{array}$ \\
\hline Registered population & 16.1 & 1.7 & 49.4 & 32.8 \\
Seasonal population & 58.8 & 0.0 & 17.0 & 24.2 \\
Average population & 37.4 & 0.0 & 38.5 & 24.1 \\
\hline
\end{tabular}

Registered population increased in urban and exurban areas, as well as in rural areas close to urban areas. Registered population in local rural centres stagnated, and core rural areas and sparsely populated rural areas experienced a severe registered population loss. There is a polarization of the registered population development: growth is directed to areas that are functionally connected to urban areas and decline to areas that are located outside the urban daily functional zones. However, the inclusion of the seasonal influx in the population statistics reduces the contrast. Seasonally, the urban areas experienced only a little population increase while most of the growth was directed to sparsely populated rural areas. Although the registered population has been concentrating, the seasonal population shows a different dynamic over time. Because 


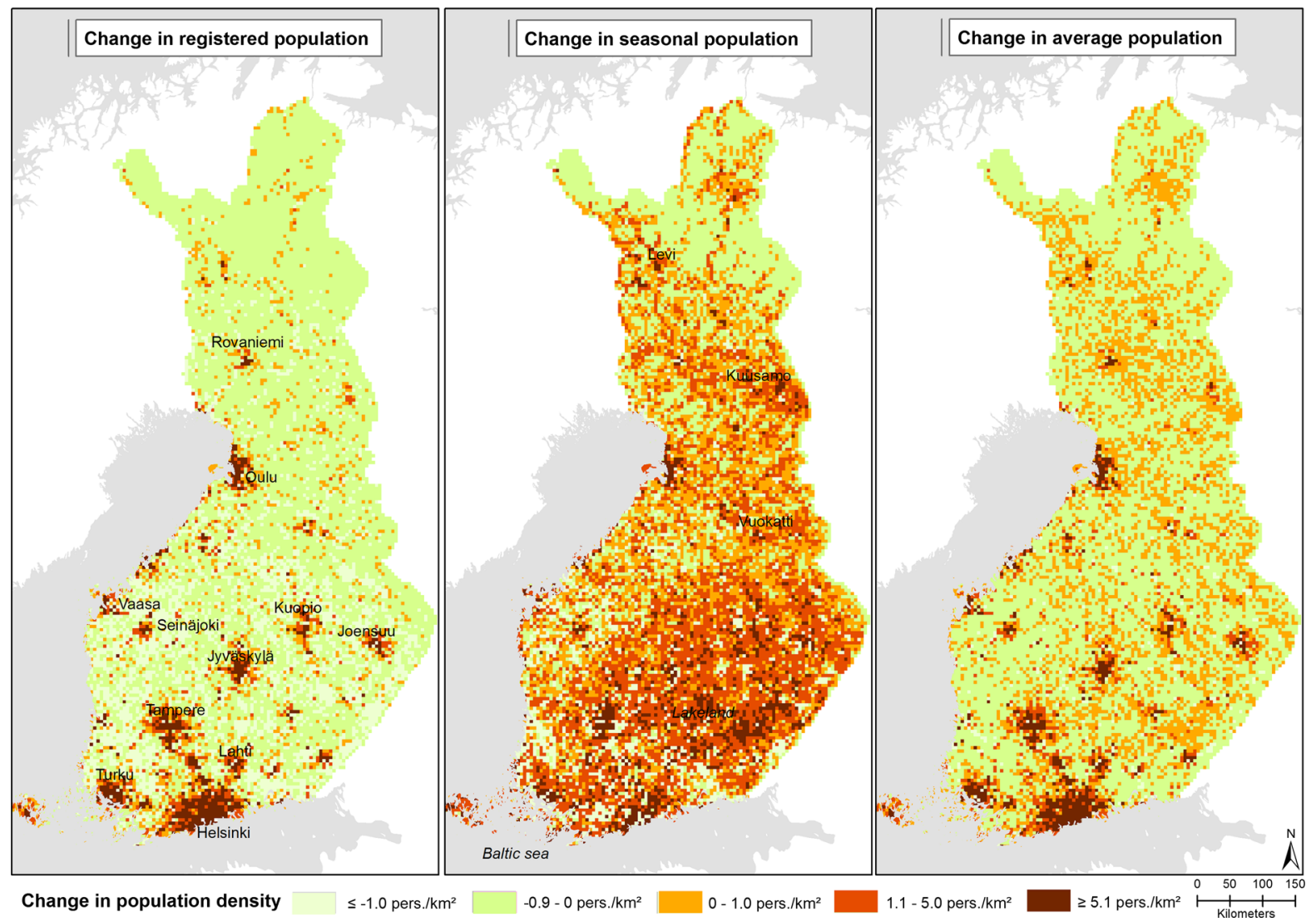

Fig. 4 Change of registered, seasonal and average population in Finland between 1990 and 2010

Table 3 Change of registered, seasonal and average population in Finland between 1990 and 2010 by category of YKR urban-rural typology

\begin{tabular}{lcrr}
\hline Category & $\begin{array}{l}\text { Registered } \\
\text { population }\end{array}$ & $\begin{array}{l}\text { Seasonal } \\
\text { population }\end{array}$ & $\begin{array}{l}\text { Average } \\
\text { population }\end{array}$ \\
\hline Urban areas (inner and outer, $\mathrm{n}=88)$ & 334,033 & 28,482 & 295,855 \\
Exurban fringe $(\mathrm{n}=570)$ & 208,174 & 31,392 & 186,648 \\
Local centres of rural areas $(\mathrm{n}=88)$ & $-11,237$ & $-28,426$ & $-13,181$ \\
Rural areas close to urban areas $(\mathrm{n}=1630)$ & 28,835 & 54,700 & 32,034 \\
Core rural areas $(\mathrm{n}=2223)$ & $-77,118$ & 28,859 & $-64,303$ \\
Sparsely populated rural areas $(\mathrm{n}=10,435)$ & $-100,443$ & 259,855 & $-57,761$ \\
\hline
\end{tabular}

of the seasonal element, also the decline of average population in rural areas is smaller than the numbers of registered population suggest.

The values of Hoover index for the three measures of population present the differences in their overall levels of concentration and changes over time (Table 4). High and growing values of the index for registered population (from $76.4 \%$ in 1990 to $79.6 \%$ in 2010) confirm its increasing spatial concentration. Much lower and declining values for seasonal population (from 65.1 to $61.1 \%$ ), in turn, prove its increasing dispersion over the country. The values for average population are close to registered population, but their increase is slower. 
Table 4 Change in Hoover index of concentration of registered, seasonal and average population in Finland between 1990 and $2010(\%)$

\begin{tabular}{llll}
\hline & 1990 & 2010 & Change \\
\hline Registered population & 76.4 & 79.6 & +3.2 \\
Seasonal population & 65.1 & 61.1 & -4.0 \\
Average population & 74.1 & 76.5 & +2.4 \\
\hline
\end{tabular}

\section{Discussion and conclusions}

Official statistics indicate that the Finnish population has increasingly concentrated in and around major cities during the recent decades. This development has been paralleled by a continuous loss of population by peripheral rural regions. However, the urban-rural population dynamics appear more complex when taking into consideration temporary mobilities as illustrated by the alternative population measurements proposed in the paper. Seasonal population assuming the highest attendance at second homes is much more spatially dispersed than registered population, and significantly outnumbers the registered population in many amenity-rich areas. Over time, contrary to registered population, seasonal population has increasingly dispersed as a result of the growth in number of second homes. Over half of the Finnish territory experienced an increase in seasonal population, compared with only $16 \%$ of territory where registered population increased. Regionally, the increase in seasonal population is the strongest in the amenity-rich areas of the sea coast, the Lakeland and the ski centres of northern Finland, while in other rural regions, particularly in western Finland, loss of registered population is not compensated by a seasonal population increase. Also, the average population figures calculated based on the average lengths of stays in second homes show that the spatial extent of rural depopulation has been in fact much smaller than registered population statistics suggest.

We have demonstrated that despite registered population being increasingly concentrated, the counterurbanization phenomenon does occur in Finland, manifested by temporary rather than permanent moves. Previous literature has linked second home mobility to counterurbanization understood as a migratory movement analysed at an individual level [Mitchell's (2004) counterurbanization]. Large-scale population studies, however, have ignored the fact that the changes in the number, distribution and patterns of use of second homes transform the whole settlement system contributing to the counterurbanizing process, thus the increasing dispersion of the settlement system. In the modern mobile world, temporary mobility should be treated as an integral part of settlement systems, and ignoring it hampers the complete understanding about population processes. Second home use produces manifold relations between urban and rural areas, it has significant physical impacts, and creates a socio-economic potential for the rural areas. The role of second homes on the counterurbanizing process over time does not only result from the growth in number of second homes, but also from changes in the patterns of their use reflecting demographic, economic, cultural and technological transformations. The increasing average time spent in second homes, growing number of households using more than one second home, and blurring boundaries between primary and secondary residences justify talking about alternate rather than first and secondary dwellings (Kaltenborn 1998; Pitkänen and Vepsäläinen 2008; Adamiak et al. 2015).

We advocate taking temporary population into account when planning local development strategies as it can contribute to the development of rural areas equally to the "permanent" registered population. Although not being registered as residents, seasonal dwellers also use local resources, infrastructure and services, and they have considerable impacts on rural land use patterns and ecosystems. Therefore, seasonal and average population measures can be helpful in a number of planning and policy fields. In the planning, scaling and management of infrastructure such as transport and telecommunication networks, water and electricity supply, waste management and green infrastructure (and, consequently, financial needs of local authorities for infrastructure maintenance and development), the measure of seasonal population developed in this study can actually be a more appropriate tool than registered population. The measure of average population, in turn, may be useful to estimate and project the demand for local public and private services. For instance, increasing year-round use of second homes and aging of their owners imply an increasing latent burden for the provision of health care services in rural areas (Åkerlund et al. 2015). A dynamic approach which takes into account not only 
changes in the number of second homes, but also in the patterns of their use, allows to forecast future changes in demand for infrastructure and services.

Besides Finland, counterurbanization processes related to second home mobility occur in other Nordic countries and elsewhere. In our study we suggested a research procedure to acknowledge the role of temporary mobility in urban-rural population dynamics. The procedure was enabled by the availability of detailed statistical information on the distribution and use of second homes, and the existence of a georeferenced statistical database, which makes a direct application of the method elsewhere challenging. Furthermore, there are some reservations in terms of the data employed which affect the completeness of the analysis. The current study focused on domestic second home flows only, but there is also a growing number of transnational second homes which are invisible to domestic statistics. Also, the increasing diversity of technical forms and patterns of use of second homes makes the approximation of time spent there based on national averages inaccurate. Moreover, the study tells little about the local patterns of population dynamics in rural areas. In fact, most second homes are cottages built on purpose in scattered settlements outside of existing villages (Adamiak et al. 2015), so the depopulation of existing villages takes place simultaneously with the growth of seasonal settlements, leading together to a complex reconfiguration of the spatial structures of rural places rather than a direct replacement (or displacement) of permanent population by seasonal residents. Such limitations are inherent to quantitative research approach, as any pre-existing statistical data is biased by the strict definitions employed by statistical agencies, which can never acknowledge the full diversity of spatial and temporal dimensions of human mobility.

This study highlights the importance of including various forms of mobility in analysing and explaining the population dynamics. The traditional notions of singular and static place of residence, migration as a shift between such static states, and the population of an area as their aggregation are increasingly ineffective in capturing the diversity of forms of mobility, including these related to multiple dwelling. Different research approaches should be applied to describe and understand the complexity of population mobility: exploratory qualitative research should be accompanied by quantitative studies using various sources of data (spatial, register, survey) to provide usable data and overcome the problem of inflexibility of traditional measurements. A better integration is also needed between different research fields addressing the urban-rural population dynamics, including population studies, rural studies, and tourism studies. Deeper understanding about the directions, drivers and transformations of the population flows of various spatial and temporal scales is crucial in explaining the current population processes, as well as for addressing effective development policies to rural and urban areas.

Acknowledgments The article was written as part of the research project "Homes beyond homes - Multiple dwelling and everyday living in leisure spaces", funded by the Academy of Finland (SA 255424).

\section{Compliance with ethical standards}

Conflict of interest There are no potential conflicts of interest.

Human and animal rights No human participants and/or animals were involved in the research.

Open Access This article is distributed under the terms of the Creative Commons Attribution 4.0 International License (http:// creativecommons.org/licenses/by/4.0/), which permits unrestricted use, distribution, and reproduction in any medium, provided you give appropriate credit to the original author(s) and the source, provide a link to the Creative Commons license, and indicate if changes were made.

\section{References}

Adamiak, C., Vepsäläinen, M., Strandell, A., Hiltunen, M. J., Pitkänen, K., Hall, C. M., et al. (2015). Second home tourism in Finland: Perceptions of citizens and municipalities on state and development of second home tourism. Reports of Finnish Environment Institute 22en/2015. Helsinki: Finnish Environment Institute. http://hdl.handle.net/ 10138/155090.

Åkerlund, U., Pitkänen, K., Hiltunen, M. J., Overvåg, K., Müller, D., \& Kahila, P. (2015). Health, well-being and second homes: An outline of current research and policy challenges. Matkailututkimus, 11(1), 43-54.

Alestalo, J. (1983). The concentration of population in Finland between 1880 and 1980. Fennia, 161(2), 263-288.

Amcoff, J. (2006). Rural population growth in Sweden in the 1990s: Unexpected reality or spatial-statistical chimera? Population, Space and Place, 12(3), 171-185. doi:10. 1002/psp.407.

Bell, M., \& Ward, G. (2000). Comparing temporary mobility with permanent migration. Tourism Geographies, 2(1), 97-107. doi:10.1080/146166800363466. 
Berry, B. J. L. (Ed.). (1976). Urbanization and counter-urbanization. Beverly Hills: Sage.

Berry, B. J. L. (1988). Migration reversals in perspective: The longwave evidence. International Regional Science Review, 11(3), 245-251. doi:10.1177/016001768801100302.

Boyle, P., \& Halfacree, K. (Eds.). (1998). Migration into rural areas: Theories and issues. Chichester: Wiley.

Buller, H., \& Hoggart, K. (1994). International counterurbanization: British migrants in rural France. Aldershot: Ashgate.

Champion, A. G. (Ed.). (1989). Counterurbanization: The changing pace and nature of population deconcentration. New York/London: Edward Arnold.

Champion, T. (2001). Urbanization, suburbanization, counterurbanization and reurbanization. In R. Paddison (Ed.), Handbook of urban studies (pp. 143-161). London: Sage.

Charles-Edwards, E., \& Bell, M. (2015). Seasonal flux in Australia's population geography: Linking space and time. Population, Space and Place, 21(2), 103-123. doi:10. 1002/psp.1814.

Coppock, J. T. (Ed.). (1977). Second homes: Curse or blessing. Oxford: Pergamon.

Dahms, F. A. (1995). 'Dying villages', 'counterurbanization' and the urban field-A Canadian perspective. Journal of Rural Studies, 11(1), 21-33. doi:10.1016/07430167(94)00051-A.

Farstad, M. (2013). Local residents' valuation of second home owners' presence in a sparsely inhabited area. Scandinavian Journal of Hospitality and Tourism, 13(4), 317-331. doi:10.1080/15022250.2013.863062.

Gallent, N., Mace, A., \& Tewdwr-Jones, M. (2005). Second homes: European perspectives and UK policies. Aldershot: Ashgate.

Geyer, H. S., \& Kontuly, T. (1993). A theoretical foundation for the concept of differential urbanization. International Regional Science Review, 15(2), 157-177. doi:10.1177/ 016001769301500202.

Gordon, P. (1979). Deconcentration without a 'clean break'. Environment and Planning A, 11(3), 281-290.

Gosnell, H., \& Abrams, J. (2011). Amenity migration: Diverse conceptualizations of drivers, socioeconomic dimensions, and emerging challenges. GeoJournal, 76(4), 303-322. doi:10.1007/s10708-009-9295-4.

Halfacree, K. (2008). To revitalise counterurbanisation research? Recognising an international and fuller picture. Population, Space and Place, 14(6), 479-495. doi:10. 1002/psp.501.

Halfacree, K. (2012). Heterolocal identities? Counter-urbanisation, second homes, and rural consumption in the era of mobilities. Population, Space and Place, 18(2), 209-224. doi:10.1002/psp.665.

Hall, C. M. (2005). Tourism: Rethinking the social science of mobility. Harlow: Pearson Education.

Hall, C. M. (2014). Second home tourism: An international review. Tourism Review International, 18(3), 115-135. doi: $10.3727 / 154427214 X 14101901317039$.

Hall, C. M., \& Müller, D. K. (Eds.). (2004). Tourism, mobility and second homes: Between elite landscape and common ground. Clevedon: Channel View.

Hätälä, J., \& Rusanen, J. (2010). Suomen aluerakenteen viimeaikainen ja tuleva kehitys. Nordia tiedonantoja 1/2010. Oulu: Multiprint oy.
Hedberg, C., \& Haandrikman, K. (2014). Repopulation of the Swedish countryside: Globalisation by international migration. Journal of Rural Studies, 34, 128-138. doi:10. 1016/j.jrurstud.2014.01.005.

Heikkilä, E. (2003). Differential urbanisation in Finland. Tijdschrift voor Economische en Sociale Geografie, 94(1), 49-63. doi:10.1111/1467-9663.00236.

Helminen, V., Nurmio, K., Rehunen, A., Ristimäki, M., Oinonen, K., Tiitu, M., et al. (2014). Kaupunki-maaseutualueluokitus: Paikkatietoihin perustuvan alueluokituksen muodostamisperiaatteet. Reports of Finnish Environment Institute, 25/2014. Helsinki: Finnish Environment Institute. http://hdl.handle.net/10138/135861.

Hiltunen, M. J., Pitkänen, K., Vepsäläinen, M., \& Hall, C. M. (2013). Second home tourism in Finland: Current trends and eco-social impacts. In Z. Roca (Ed.), Second homes in Europe: Lifestyle issues and policy responses (pp. 165-200). Farnham: Ashgate.

Hoggart, K. (1997). Rural migration and counterurbanization in the European periphery: The case of Andalucia. Sociologia Ruralis, 37(1), 134-153. doi:10.1111/1467-9523.00040.

Hoover, E. M. (1941). Interstate redistribution of population, 1850-1940. The Journal of Economic History, 1(2), 199-205.

Jaakson, R. (1986). Second-home domestic tourism. Annals of Tourism Research, 13(3), 367-391. doi:10.1016/01607383(86)90026-5.

Jauhiainen, J. S. (2009). Will the retiring baby boomers return to rural periphery? Journal of Rural Studies, 25(1), 25-34. doi:10.1016/j.jrurstud.2008.05.001.

Johnson, K. M., Nucci, A., \& Long, L. (2005). Population trends in metropolitan and nonmetropolitan America: Selective deconcentration and the rural rebound. Population Research and Policy Review, 24(5), 527-542. doi:10.1007/ s11113-005-4479-1.

Kaltenborn, B. P. (1998). The alternate homes-Motives of recreation home use. Norwegian Journal of Geography, 52(3), 121-134. doi:10.1080/00291959808552393.

Kauppila, P., \& Rusanen, J. (2009). A grid cell viewpoint to resorts: Case studies in northern Finland. Scandinavian Journal of Hospitality and Tourism, 9(1), 1-21. doi:10. 1080/15022250802711039.

Kontuly, T., \& Vogelsang, R. (1988). Explanations for the intensification of counterurbanization in the Federal Republic of Germany. The Professional Geographer, 40(1), 42-54. doi:10.1111/j.0033-0124.1988.00042.x.

Kotavaara, O., Antikainen, H., \& Rusanen, J. (2011). Population change and accessibility by road and rail networks: GIS and statistical approach to Finland 1970-2007. Journal of Transport Geography, 19(4), 926-935. doi:10.1016/j. jtrangeo.2010.10.013.

Kupiszewski, M., Heikkilä, E., Nieminen, M., Durham, H., Rees, P., \& Kupiszewska, D. (2000). Internal migration and regional population dynamics in Europe: Finland case study. Working paper. University of Leeds, School of Geography.

Lehtonen, O. (2015). Space-time dependence in regional development: The geospatial approach to understanding the development processes in small-scale areas in Finland. Dissertations in Social Sciences and Business Studies 105. Joensuu/Kuopio: University of Eastern Finland. http:// epublications.uef.fi/pub/urn_isbn_978-952-61-1765-2. 
Lehtonen, O., \& Tykkyläinen, M. (2009). Regional formations and pulse of migration in Finland, 1980-2006. Terra, 121(2), 119-137.

Lehtonen, O., \& Tykkyläinen, M. (2010). Self-reinforcing spatial clusters of migration and socio-economic conditions in Finland in 1998-2006. Journal of Rural Studies, 26(4), 361-373. doi:10.1016/j.jrurstud.2010.02.003.

LVVI. (2000). Recreational use of forests-Results of the 2000 LVVI demand study. The Finnish Forest Research Institute (Metla). http://www.metla.fi/metinfo/monikaytto/lvvi/en/ tietoa-valtakunnalliset-tilastot-en.htm.

LVVI. (2010). Recreational use of forests-Outdoor recreation statistics 2010. The Finnish Forest Research Institute (Metla). http://www.metla.fi/metinfo/monikaytto/lvvi/en/ tietoa-ulkoilusta-2010-en.htm.

Magnusson, L., \& Turner, B. (2003). Countryside abandoned? Suburbanization and mobility in Sweden. European Journal of Housing Policy, 3(1), 35-60. doi:10.1080/ 1461671032000071173.

Marjavaara, R. (2008). Second home tourism: The root to displacement in Sweden? Doctoral dissertation. Umeå University, Department of Social and Economic Geography.

Marjavaara, R., \& Lundholm, E. (2014). Does second-home ownership trigger migration in later life? Population, Space and Place, 22(3), 228-240. doi:10.1002/psp.1880.

McCarthy, J. (2008). Rural geography: Globalizing the countryside. Progress in Human Geography, 32(1), 129-137. doi:10.1177/0309132507082559.

McGranahan, D. A. (2008). Landscape influence on recent rural migration in the U.S. Landscape and Urban Planning, 85(3-4), 228-240. doi:10.1016/j.landurbplan.2007.12.001.

McIntyre, N., Williams, D. R., \& McHugh, K. E. (Eds.). (2006). Multiple dwelling and tourism: Negotiating place, home and identity. Wallingford: CABI.

Milbourne, P. (2007). Re-populating rural studies: Migrations, movements and mobilities. Journal of Rural Studies, 23(3), 381-386. doi:10.1016/j.jrurstud.2007.04.002.

Mitchell, C. J. A. (2004). Making sense of counterurbanization. Journal of Rural Studies, 20(1), 15-34. doi:10.1016/ S0743-0167(03)00031-7.

Moss, L. A. G. (Ed.). (2006). The amenity migrants: Seeking and sustaining mountains and their cultures. Wallingford: CABI.

Muilu, T., \& Rusanen, J. (2003). Rural young people in regional development-The case of Finland in 1970-2000. Journal of Rural Studies, 19(3), 295-307. doi:10.1016/S07430167(03)00003-2.

Müller, D. K. (2002). Second home ownership and sustainable development in Northern Sweden. Tourism and Hospitality Research, 3(4), 343-355.

Müller, D. K. (2011). Second homes in rural areas: Reflections on a troubled history. Norwegian Journal of Geography, 65(3), 137-143. doi:10.1080/00291951.2011.597872.

Müller, D. K., \& Hall, C. M. (2003). Second homes and regional population distribution: On administrative practices and failures in Sweden. Espace, Populations, Sociétés, 2003(2), 251-261. doi:10.3406/espos.2003.2079.

Niedomysl, T., \& Amcoff, J. (2011). Is there hidden potential for rural population growth in Sweden? Rural Sociology, 76(2), 257-279. doi:10.1111/j.1549-0831.2010.00032.x.
Nieminen, M. (2009). Kesämökkibarometri 2009. Ministry of Employment and the Economy, and Statistics Finland. http://www.tem.fi/files/22175/Mokkibaro08_raportti.pdf.

OSF. (2015). Buildings and free-time residences. Helsinki: Statistics Finland. http://www.tilastokeskus.fi/til/rakke/ 2014/rakke_2014_2015-05-28_kat_001_en.html.

Pehkonen, A. (2005). Why people migrated to the countryside in Finland in the 1990s? Migration Letters, 2(2), 153-163.

Pekkala, S. (2003). Migration flows in Finland: Regional differences in migration determinants and migrant types. International Regional Science Review, 26(4), 466-482. doi:10.1177/0160017603259861.

Phillips, M. (2010). Counterurbanisation and rural gentrification: An exploration of the terms. Population, Space and Place, 16(6), 539-558. doi:10.1002/psp.570.

Pitkänen, K., \& Vepsäläinen, M. (2008). Foreseeing the future of second home tourism. The case of Finnish media and policy discourse. Scandinavian Journal of Hospitality and Tourism, 8(1), 1-24. doi:10.1080/15022250701880729.

Ragatz, R. L. (1970). Vacation homes in the northeastern United States: Seasonality in population distribution. Annals of the Association of American Geographers, 60(3), 447-455. doi:10.1111/j.1467-8306.1970.tb00734.x.

Rigall-i-Torrent, R. (2010). Estimating overnight de facto population by forecasting symptomatic variables: An integrated framework. Journal of Forecasting, 29(7), 635-654. doi:10.1002/for.1166.

Rogerson, P. A., \& Plane, D. A. (2012). The Hoover index of population concentration and the demographic components of change: An article in memory of Andy Isserman. International Regional Science Review, 36(1), 97-114. doi:10.1177/0160017612440811.

Rye, J. F. (2006). Leaving the countryside: An analysis of rural-tourban migration and long-term capital accumulation. Acta Sociologica, 49(1), 47-65. doi:10.1177/0001699306061899.

Silm, S., \& Ahas, R. (2010). The seasonal variability of population in Estonian municipalities. Environment and Planning A, 42(10), 2527-2546. doi:10.1068/a43139.

Šimon, M. (2012). Exploring counterurbanisation in a post-socialist context: Case of the Czech Republic. Sociologia Ruralis, 54(2), 117-142. doi:10.1111/j.1467-9523.2012. 00576.x.

Stockdale, A. (2002). Towards a typology of out-migration from peripheral areas: A Scottish case study. International Journal of Population Geography, 8(5), 345-364. doi:10. 1002/ijpg. 265.

Stockdale, A. (2006). The role of a 'retirement transition' in the repopulation of rural areas. Population, Space and Place, 12(1), 1-13. doi:10.1002/psp.380.

Terrier, C. (Ed.). (2006). Mobilité touristique et population présente, les bases de l'économie présentielle des départements. Paris: Direction du Tourisme.

Tisdale, H. (1942). The process of urbanization. Social Forces, 20(3), 311-316.

Urry, J. (2007). Mobilities. Cambirdge: Polity.

van der Berg, L., Drewett, R., Klaassen, L. H., Rossi, A., \& Vijverberg, C. H. T. (1982). Urban Europe: A study of growth and decline (Vol. 1). Oxford: Pergamon.

Vartiainen, P. (1989a). Counterurbanisation: A challenge for socio-theoretical geography. Journal of Rural Studies, 5(3), 217-225. 
Vartiainen, P. (1989b). The end of drastic depopulation in rural Finland: Evidence of counterurbanisation? Journal of Rural Studies, 5(2), 123-136.

Vining, D. R. J., \& Strauss, A. (1977). A demonstration that the current deconcentration of population in the United States is a clean break with the past. Environment and Planning A, 9(7), 751-758. doi:10.1068/a090751.

Williams, A. M., \& Hall, C. M. (2000). Tourism and migration: New relationships between production and consumption. Tourism Geographies, 2(1), 5-27. doi:10.1080/146166800363420. 